\title{
FIRST RECORD OF CYRNUS CRENATICORNIS (KOLENATI, 1859) (INSECTA, TRICHOPTERA, POLYCENTROPODIDAE) IN CROATIA: MORPHOLOGICAL DETERMINATION AND DNA BARCODING
}

\author{
Renata Ćuk ${ }^{1}$, Mladen Kučinića ${ }^{2}$, Lidija Kladarići ${ }^{1}$, Dora Hlebec ${ }^{2,3}$, \\ VJeRAN Đanić ${ }^{1} \&$ Maja Miličićc ${ }^{1}$
}

${ }^{1}$ Hrvatske vode, Central Water Management Laboratory, Ulica grada Vukovara 220, 10000 Zagreb, Croatia

${ }^{2}$ Department of Biology, Faculty of Science, University of Zagreb, Rooseveltov trg 6, 10000 Zagreb, Croatia

${ }^{3}$ Zoological Museum Hamburg, Leibniz Institute for the Analysis of Biodiversity Change (LIB), Martin-Luther-King-Platz 3, 20146 Hamburg, Germany

Ćuk, R., Kučinić, M., Kladarić, L., Hlebec, D., Đanić, V. \& Miličić, M.: First record of Cyrnus crenaticornis (Kolenati, 1859) (Insecta, Trichoptera, Polycentropodidae) in Croatia: morphological determination and DNA barcoding. Nat. Croat., Vol. 30, No. 2, 405-416, Zagreb, 2021.

The caddisfly species Cyrnus crenaticornis (Kolenati, 1859) was recorded for the first time in Croatia in the Odra River during August 2015. The record refers to a larval stage which was determined according to morphological characteristics and supported by DNA barcoding.

Key words: caddisflies, larva, new record, Odra River, continental Croatia

Ćuk, R., Kučinić, M., Kladarić, L., Hlebec, D., Đanić, V. \& Miličić, M.: Prvi nalaz tulara Cyrnus crenaticornis (Kolenati, 1859) (Insecta, Trichoptera, Polycentropodidae) u Hrvatskoj: morfološka determinacija i DNA barkodiranje. Nat. Croat., Vol. 30, No. 2, 405-416, Zagreb, 2021.

Tular Cyrnus crenaticornis (Kolenati, 1859) je po prvi puta utvrđen u Hrvatskoj u rijeci Odri u kolovozu 2015. godine. Vrsta je utvrđena na temelju morfološke determinacije ličinke, a potvrđena je primjenom metode DNA barkodiranja.

Ključne riječi: tulari, ličinka, novi nalaz, rijeka Odra, kontinentalna Hrvatska

\section{INTRODUCTION}

One of the most frequent groups of benthic macroinvertebrates in running freshwater ecosystems is Trichoptera (caddisflies). They inhabit almost every type of habitat, but their biodiversity is greatest in streams and small rivers (WALLACE et al., 1990). The Trichoptera World Checklist counts 16,267 species in 632 genera of 63 families, including 521 fossil species, 133 fossil genera and 20 fossil families (Morse, 2021). The Western Palearctic, which includes Europe, contributes with $13.9 \%$, or 1,888 species. In Croatia, caddisflies are among the best studied orders of insects, with a certain amount of literature; however, in some cases lack of georeferenced data or sampling data as well as of information on the depository, decreases the value of these data. Systematic studies of Trichoptera based on adults started relatively recently in Croa- 
tia with fieldwork in the Plitvice Lakes National Park (e.g. KučInIĆ, 2002; KučinIĆ \& Malicky, 2002; Kučinić et al., 2017; Marinković-Gospodnetić, 1971, 1979; Previšić et al., 2007a, 2010) and later in different, often restricted parts of Croatia e.g. the Krka River (KuČInić et al., 2011, 2019; Ridl et al., 2015; VALladolid et al., 2020), the Cetina River catchment area (Graf et al., 2008a; Previšić et al., 2014; VučKović et al., 2011, 2021; Waringer et al., 2009), the Drava River (Previšić et al., 2007b), Gorski kotar area (Cerjanec et al., 2020; Malicky et al., 2007; Previšić \& Popijač, 2010), Banovina area (Kučinić et al., 2010, 2020b), Mt Papuk (Previšıć et al., 2013), and some individual researches in the inland part of Croatia (e.g. Ćukušić et al., 2017; Kučinić et al., 2020b; Malicky \& KruŠnik, 1988; Malicky, 2009, 2014; OláH, 2011; Szivák et al., 2017; Vrućina et al., 2016). On the other hand, studies on caddis larvae are much more scarce due to the lack of experts, and beside the description sometimes having to deal with previously unknown larvae (e.g. Graf et al., 2008a; KarAOUZAS et al., 2015; Kučinić et al., 2008; Previšić et al., 2014; Waringer et al., 2009, they mostly originate from studies related to the biomonitoring of surface water quality that report new records (Ćuk \& VuČKović, 2009, 2010, 2014; Ćuk et al., 2015). Sometimes they will be found as a part of the macrozoobenthic community (Habdja \& Primc, 1987; Habdja et al., 1994, 1997, 2000, 2002, 2003, 2004; MatoničKin \& Pavletić, 1961, 1965; MatoničKin et al., 1969, 2001; RAĐA \& Puljas, 2010).

DNA barcoding is a molecular method based on sequencing of the barcode region (658 bp in length) of the cytochrome c oxidase subunit I gene (COI) to aid species identification (Hebert et al., 2003a, 2003b; Ratnasingham \& Hebert, 2007) and has significantly contributed to the knowledge of biodiversity, taxonomy and phylogeny of different groups of organisms (e.g. AMORA et al., 2015; BĄCZKIEwicz et al., 2017; Cárdenas et al., 2013; Dela Cruz et al., 2016; Elías-Gutiérrez et al., 2008, KuČinić et al., 2020a, Morinière et al., 2017, Vijayan \& Tsou, 2010). This method is very useful for the determination of morphologically very similar species, and also the finding of cryptic species (e.g. Kučinić et al., 2013; Tyagi et al., 2017; VAGlia et al., 2008; VAllaDOLID et al., 2020). According to BACCZKIEwicz et al. (2017): "DNA barcoding is a highly useful method for identifying taxonomically difficult species". In the last few years, the DNA barcoding method has been applied in the biodiversity research of Trichoptera in Croatia, including faunistic (e.g. Cerjanec et al., 2020; Ćukušić et al., 2017; KuČinić et al., 2020b; VučKović et al., 2021) and taxonomic research (Kučinić et al., 2013, 2020a; VALLADOLID et al., 2020).

This paper presents the first record of Cyrnus crenaticornis (KolenaTI, 1859) in Croatia, the presence of which is confirmed with application of DNA barcoding.

\section{MATERIAL AND METHODS}

Research area. The Odra River is situated in the Hungarian lowland ecoregion (Pannonian) (ER11) (Illies, 1978) and belongs to the catchment area of the Sava River. It is an inland river and is $45.5 \mathrm{~km}$ long. According to national typology, the Odra River is classified among "Medium and large lowland rivers" (HR-R_4) (Official GazeTte, 2013). The study site on the Odra River is located at the settlement of Čička Poljana (N45 $\left.40^{\prime} 26,9^{\prime \prime}, \mathrm{E} 16^{\circ} 10^{\prime} 36,8^{\prime \prime}\right)$ (Fig. 1a). The dominant substrate was psammopelal with $100 \%$ coverage of submerged and emerged macrophyte in the littoral zone where the sample was taken (HRN EN 16150, 2012) (Fig. 1b). 


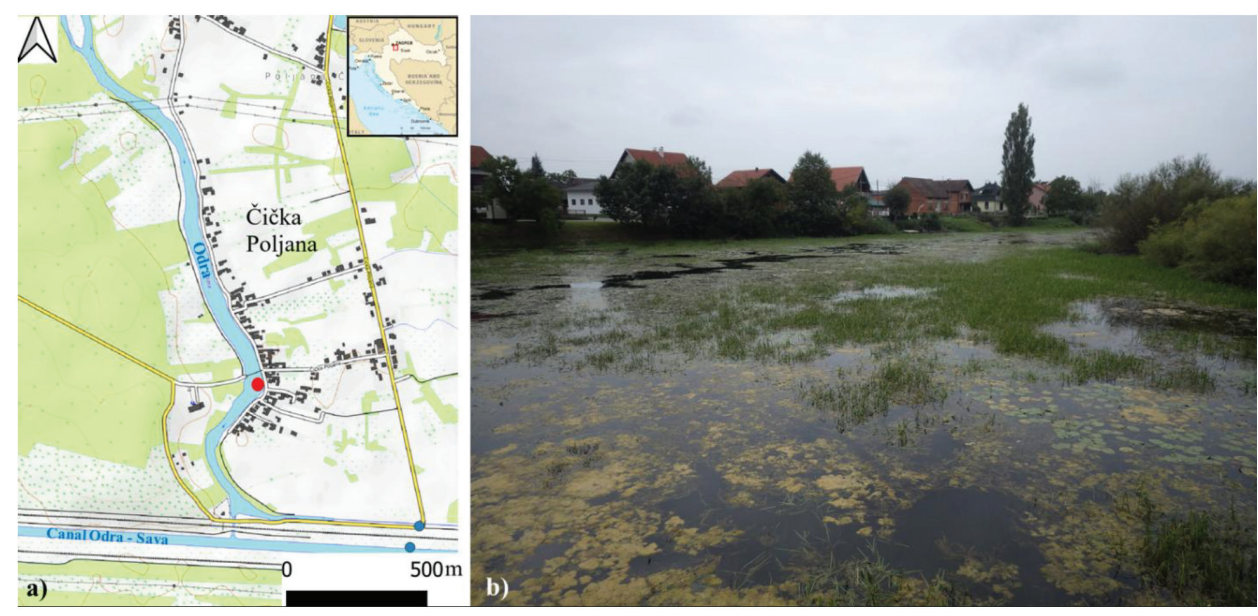

Fig. 1. Distribution of Cyrnus crenaticornis in Croatia: a) record in Croatia (red spot) with a detail of the study area; b) the Odra River at Čička Poljana

Sampling and laboratory work. Sampling of benthic macroinvertebrates was conducted on August 27 2015 using a hand net with a mesh size of $500 \mu \mathrm{m}$ according to the AQEM sampling protocol (AQEM ConsorTIUm, 2002). The collected material was preserved in ethanol in the field so the final concentration was approximately $70 \%$. Isolation and determination of benthic macroinvertebrates were done in the laboratory using a binocular stereomicroscope (Olympus SZX10). Additional larvae (3 specimens) were collected on June $13^{\text {th }} 2021$ and stored in absolute ethanol. For species determination the keys of Waringer \& Graf (2011) and Lechthaler \& Stockinger (2007) were used. All specimens have been deposited in the collection of caddisflies in the Central Water Management Laboratory of Hrvatske vode.

Water samples were collected monthly in 2015 at the study site and the following physical-chemical parameters were analysed according to standard analytical methods for assessment of surface water quality (ISO norms): $\mathrm{pH}$, biological oxygen demand $\left(\mathrm{BOD}_{5}\right)\left(\mathrm{mgO}_{2} / 1\right)$, chemical oxygen demand (COD-Mn) $\left(\mathrm{mgO}_{2} / \mathrm{l}\right)$, ammonia $\left(\mathrm{NH}_{4}^{+}\right)(\mathrm{mgN} / 1)$, nitrates $\left(\mathrm{NO}_{3}^{-}\right)(\mathrm{mgN} / 1)$, total nitrogen $(\mathrm{mgN} / 1)$, ortophosphates $\left(\mathrm{PO}_{4}{ }^{3-}\right)(\mathrm{mgP} / \mathrm{l})$, total phosphorus $(\mathrm{mgP} / \mathrm{l})$.

DNA extraction, amplification and sequencing. DNA barcoding was performed using one of the newly collected larvae in 2021. Total genomic DNA was extracted from two legs (1 larva) using GenElute Mammalian Genomic DNA Miniprep kit (Sigma-Aldrich, Germany) following the manufacturer's protocol and eluted in $50 \mu \mathrm{L}$ of elution buffer. The standard DNA barcode region (658 bp) of the mitochondrial cytochrome c oxidase subunit I gene (COI) was amplified with the use of standard PCR-protocol and universal primer pair LCO-1490/HCO-2198 (FolmER et al., 1994) in $20 \mu \mathrm{L}$ reaction mixture. Polymerase chain reactions (PCRs) were carried out using: $1 \mathrm{x}$ DreamTaq ${ }^{\mathrm{TM}}$ reaction buffer with $2 \mathrm{mM} \mathrm{MgCl}_{2}$ (Thermo Fisher Scientific Inc., US), 0.2 $\mathrm{mM}$ dNTPs, $0.4 \mu \mathrm{M}$ of each primer, $0.025 \mathrm{U} / \mu \mathrm{L}$ of DreamTaq polymerase (Thermo Fisher Scientific Inc., US) and $1 \mu 1$ of eluted DNA. The PCR cycling protocol included: initial denaturation at $95^{\circ} \mathrm{C}$ for $2 \mathrm{~min}$, followed by 35 cycles of denaturation at $95^{\circ} \mathrm{C}$ 
for $30 \mathrm{~s}$, annealing at $50{ }^{\circ} \mathrm{C}$ for $30 \mathrm{~s}$, extension at $72{ }^{\circ} \mathrm{C}$ for $1 \mathrm{~min}$, followed by a final extension step at $72{ }^{\circ} \mathrm{C}$ for $10 \mathrm{~min}$. Purification and sequencing were performed by Macrogen Inc. (Amsterdam, Netherlands) using the same amplification primers. Sequence obtained in this study were deposited in the Barcode of Life Database (RATNASINGHAM \& HeberT, 2007) under the accession number CROTR362-21.

Sequence data and phylogenetic analysis. Sequence was checked, edited, assembled from both directions, and inspected manually for base pair ambiguities, as well as stop codons, indels or double peaks in chromatograms in Geneious R6 (https:/ / www.geneious.com). All available Cyrnus sequences were retrieved from the GenBank and BOLD database (accessed on July 20 $0^{\text {th }}$ 2021) and aligned with the sequence from this study using MAFFT v.7 (KaTOH \& Standley, 2013). Sequences were collapsed into 42 unique COI haplotypes using the online tool FaBox v.1.5 (VILlesen, 2007). The most diverse haplotypes were included in further analysis and the final data set for phylogenetic analysis comprised 22 sequences. Limnephilus flavicornis (CROAA008-18) was selected as outgroup. Uncorrected $p$-distances between haplotypes were calculated using MEGA-X (KumAR et al., 2018). BOLD Identification Engine (accessed on July 20th 2021) was used for comparison of obtained DNA sequence with sequences available in BOLD database. BOLD IDs and accession numbers for all specimens included in final data set are given in Tab. 1. Phylogenetic analysis was performed in MEGA-X (KumAr et al., 2018) and phylogenetic relationships were estimated by two different optimality criteria: neighbour joining (NJ) and maximum likelihood (ML). NJ was made using the Kimura-2-parameter (K2P) model of nucleotide substitution with pairwise deletion option and the robustness of the clades was assessed through 5000 bootstrap replicates. For ML the optimal model of nucleotide evolution (GTR+I) was selected under the Bayesian information criterion (BIC) using jModelTest 2.1.5 (DARRIBA et al., 2012). Nearest-Neighbour-Interchange (NNI), a heuristic method using the fast bootstrap algorithm, was used in ML with 2000 replicates.

\section{RESULTS AND DISCUSSION}

Twenty-one (21) larval specimens of C. crenaticornis (Fig. 2a) were documented in the Odra River at Čička Poljana during August 2015 and three (3) specimens in June 2021, representing thus the first record of this species in Croatia. According to WARINGER \& GRAF (2011) the characteristics of the larva are following: basal segment of anal proleg has numerous bristles, with short spines lacking from the ventral side of the ninth abdominal segment (Fig. 2b), inner apex of anal claw has four blunt teeth (Fig. 2c), the transverse row of dark spots is situated within the pale central frontoclypeal area, posterior angle of frontoclypeus without pale spot and pale patch at the center of frontoclypeus without dark anterior border (Fig. 2d).

Molecular analysis based on the obtained sequence of the DNA barcode region (658 bp long) confirmed the morphological identification and identified the obtained sequence as Cyrnus crenaticornis. Uncorrected p-distance to the single C. crenaticornis sequence (specimen with sampling site in Denmark) available in BOLD database is 0.0001 .

The topology of NJ and ML trees was congruent, with only a few weakly supported nodes (Fig. 3). Sequences of C. crenaticornis group together in a 100\% BS-supported clade, with $C$. crenaticornis being recovered as sister to C. fennicus. 

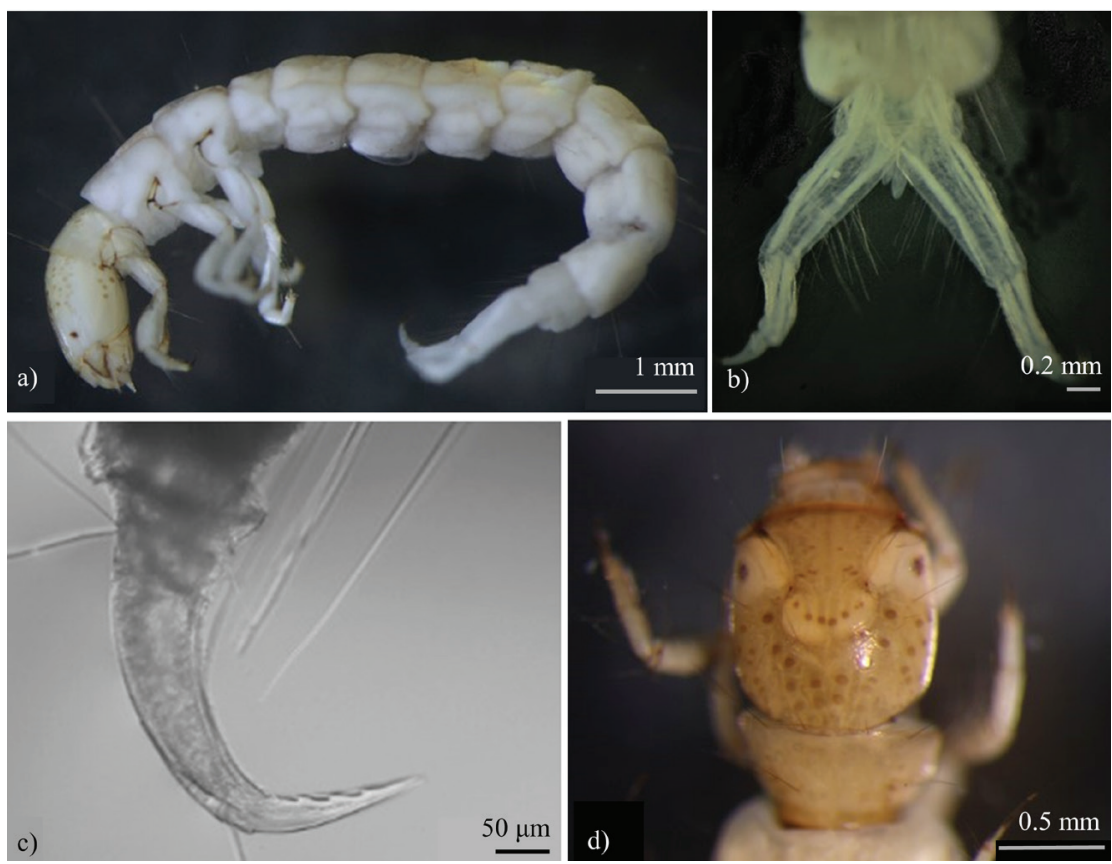

Fig. 2. Cyrnus crenaticornis, a) larva; b) tip of abdomen, ventral view; c) anal claw; d) head, dorsal view

Tab. 1. Specimens and sequences used in the analysis. Newly obtained sequence is marked in bold.

\begin{tabular}{|c|c|c|c|}
\hline Species name & Country & Sample ID & BOLD sequence ID \\
\hline \multirow{7}{*}{ Cyrnus trimaculatus } & Croatia & TPFLA_2 & CROAA129-18 \\
\hline & \multirow{2}{*}{ Germany } & GBOL00309 & FBAQU1465-13 \\
\hline & & BC ZSM AQU 00348 & FBAQU348-09 \\
\hline & Belgium & UA-SG-TRICH-C46 & TFLAN135-11 \\
\hline & Netherlands & MK093958 & GBMNA42546-19 \\
\hline & \multirow{2}{*}{ Germany } & 08JPCAD-068 & JPCAD068-08 \\
\hline & & 08JPCAD-069 & JPCAD069-08 \\
\hline \multirow{2}{*}{ Cyrnus crenaticornis } & Croatia & CC1A & CROTR362-21 \\
\hline & Denmark & JSlk-2013F077 & TRIFI1002-13 \\
\hline \multirow{2}{*}{ Cyrnus fennicus } & \multirow{2}{*}{ Japan } & 08JPCAD-081 & JPCAD081-08 \\
\hline & & 08JPCAD-083 & JPCAD083-08 \\
\hline \multirow{2}{*}{ Cyrnus insolutus } & Sweden & JQ239776 & GBMIN18566-13 \\
\hline & Finland & ARin-2011F193 & TRIFI733-12 \\
\hline \multirow{2}{*}{ Cyrnus nipponicus } & \multirow{2}{*}{ Japan } & 08JPCAD-074 & JPCAD074-08 \\
\hline & & 08JPCAD-075 & JPCAD075-08 \\
\hline \multirow{6}{*}{ Cyrnus flavidus } & \multirow{2}{*}{ Finland } & JSlk-20090083 & TRIFI188-10 \\
\hline & & JSlk-20090084 & TRIFI189-10 \\
\hline & Norway & BI2019_E07 & STUBA007-12 \\
\hline & Germany & BC ZSM AQU 00109 & FBAQU109-09 \\
\hline & \multirow{2}{*}{ Norway } & FinnCAD-003 & FINNT046-12 \\
\hline & & TRD-TRI4 & ODTRI022-14 \\
\hline
\end{tabular}




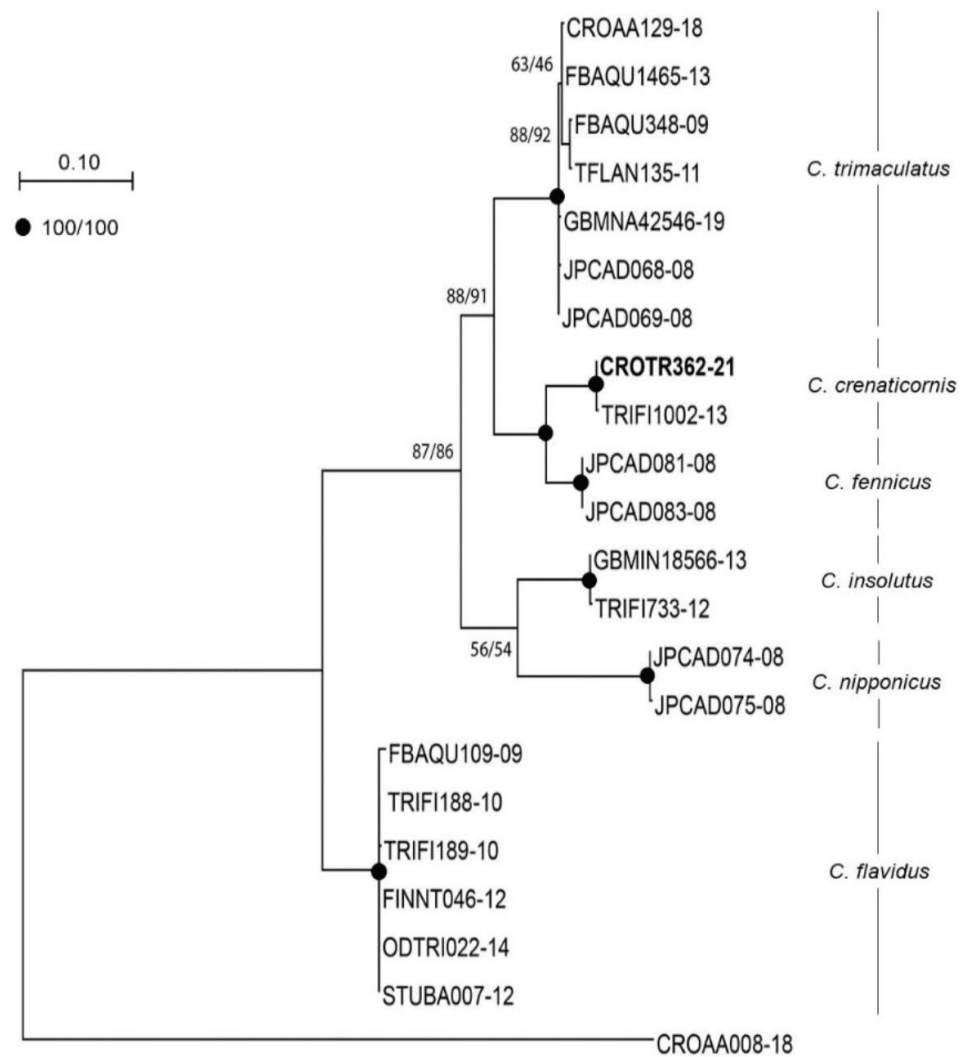

Fig. 3. Maximum likelihood phylogenetic tree based on the COI sequence of Cyrnus crenaticornis from Croatia and haplotypes of Cyrnus species from BOLD database. Numbers at the nodes indicate neighbour joining (NJ) and maximum likelihood (ML) ultrafast bootstrap support values (BS). Terminal codes present BOLD Process ID, as in Tab. 1.

According to Graf et al. (2008b), Malicky (2004, 2013) and Morse (2021) seven (7) species of the genus Cyrnus are present in Europe: C. cintranus McLachlan, 1884, C. crenaticornis (Kolenati, 1859), C. fennicus Klingstedt, 1937, C. flavidus McLachlan, 1864, C. insolutus McLachlan, 1878, C. monserrati Gonzalez \& Otero, 1983 and C. trimaculatus (Curtis, 1834), the last of which has been recorded in Croatia relatively frequently, in the Pannonian-Peripannonian, Central-mountain and Mediterranean areas (e.g. Cerjanec et al., 2020; KuČInić et al., 2017, 2020b; VučKović et al., 2021). However, the distribution of C. crenaticornis in Europe (MALICKY, 2013) indicates that although the species could have been expected to occur in Croatia (see Fig. 4), no previous records existed. The species has a wide range of distribution, occurring mostly in the littoral zone of standing waters (above $18^{\circ} \mathrm{C}$ ) usually on living plants, mainly on macrophytes, very rare on algae; prefers lower altitudes mainly plains $(<300 \mathrm{~m})$ but also 300-800 m (GRAF et al. 2008b). The sampling site on the Odra River completely fits in the above-mentioned ecological preferences of the species, as the record refers to the littoral zone of a very slow flowing watercourse, on macrophyte vegetation.

We present the taxa list of the most common species in the benthic community found at this site: mayflies (Ephemeroptera): Caenis sp. and Cloeon dipterum (Lin- 


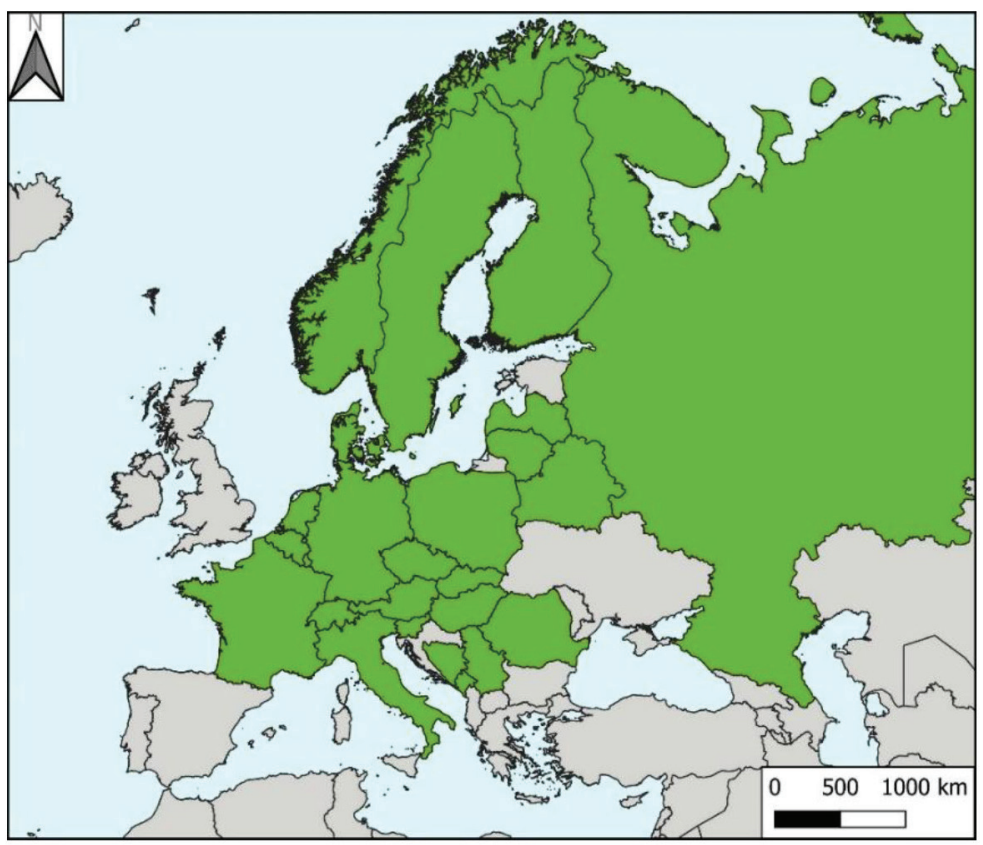

Fig. 4. Distribution of C. crenaticornis in Europe (MALICKY, 2013)

naeus, 1761), beetle (Coleoptera) Haliplus sp., leach (Hirudinea) Erpobdella octoculata (Linnaeus, 1758), snail (Gastropoda) Gyraulus sp. Caddisflies recorded at the sampling site were Athripsodes sp. and Leptocerus tineiformis (Curtis, 1834). Macroinvertebrate assemblage at the study site indicates good water status regarding saprobity module, however, regarding general degradation module, the study site is classified into poor water status and therefore does not meet the Water Framework Directive (WFD) criteria.

According to the basic physical-chemical parameters at the study site (Tab. 2) the water does not meet the WFD criteria due to the increased concentrations of nitrates and total nitrogen. Other physical-chemical parameters investigated indicate high status (Official Gazette, 2013).

Tab. 2. Annual $(n=12)$ median value of basic physical-chemical parameters in the Odra River at Čička Poljana in 2015 (the associated colour corresponds to the water status according to national methodology; blue = high status; green = good status; yellow = below good status)

\begin{tabular}{|c|c|}
\hline physical-chemical parameter & median value \\
\hline $\mathrm{pH}$ & 7,85 \\
\hline $\mathrm{BOD}_{5}\left(\mathrm{mgO}_{2} / \mathrm{l}\right)$ & 1 \\
\hline $\mathrm{COD}_{-} \mathrm{Mn}_{\left(\mathrm{mgO}_{2} / \mathrm{l}\right)}$ & 1,7 \\
\hline Ammonia $(\mathrm{mgN} / \mathrm{l})$ & 0,0355 \\
\hline Nitrates $(\mathrm{mgN} / \mathrm{l})$ & 2,105 \\
\hline Total $\mathrm{N}(\mathrm{mgN} / \mathrm{l})$ & 2,53 \\
\hline Ortophosphates $(\mathrm{mgP} / \mathrm{l})$ & 0,0095 \\
\hline Total $\mathrm{P}(\mathrm{mgP} / \mathrm{l})$ & 0,034 \\
\hline
\end{tabular}


The Trichoptera fauna of Croatia counts approximately 210 species (e.g. CerJaneC et al., 2020; Ćuk \& VuČKoviĆ, 2009, 2010, 2014; Ćuk et al. 2015; KLADARIĆ et al., 2021; KuČinić et al., 2019, 2020a; Malicky \& Krušnik, 1988; Malicky et al., 2007; Malicky, 2009, 2014; Marinković-Gospodnetić, 1971, 1979; Olah, 2011; Previšić et al., 2013, 2014; VučKović et al., 2021), most of which have been determined morphologically based on adult specimens, and recently sometimes additionally with the application of DNA barcoding (e.g. CERJANec et al., 2020; Ćukušić et al., 2017; KuČinić et al., 2013, 2019, 2020a, 2020b; SzivÁk et al., 2017; VALladolid et al., 2020; VučKović et al., 2021). New records determined on the basis of morphological characteristics of larvae are rare (e.g. Ćuk \& VučKović, 2009, 2010, 2014; Ćuk et al., 2015), not only due to the lack of expert knowledge and determination keys, but also due to a certain number of larvae expected to occur in Croatia based on their area of distribution not having been described. The national monitoring programme of surface water quality promises to result in new records, as caddisfly larvae are part of the benthic macroinvertebrate assemblage that are sampled regularly at a large number of sampling stations all over the country. Therefore, more attention should be given to larvae in general, as they might provide valuable information.

\section{ACKNOWLEDGEMENTS}

This research was supported by funding from the Croatian Science Foundation by the scientific project "DNA barcoding of Croatian faunal biodiversity" (IP-2016-069988, Project leader: Professor Mladen Kučinić) and Dora Hlebec through ESF (DOK2018-09-1417).

Received August 3, 2021

\section{REFERENCES}

Amora, G., Hamada, N., Fusari, L. M. \& Andrade-Souza, V., 2015: An Asiatic Chironomid in Brazil: morphology, DNA barcode and bionomics. ZooKeys 514, 129-144.

AQEM Consortium, 2002: Manual for the application of the AQEM system: a comprehensive method to assess European streams using benthic macroinvertebrates, developed for the purpose of the Water Framework Directive. Version 1.0, February 2002, 202 pp.

Bączkiewicz, A., Szczecińska, M., Jakub Sawicki, J., Adam Stebel, A. \& Buczkowska, K., 2017: DNA barcoding, ecology and geography of the cryptic species of Aneura pinguis and their relationships with Aneura maxima and Aneura mirabilis (Metzgeriales, Marchantiophyta). PLoS ONE 12(12): e0188837.

Cárdenas, P., Rapp, H. T., Klitgaard, B. A., Best, M., Thollesson, M. \& Tenda, O. S., 2013: Taxonomy, biogeography and DNA barcodes of Geodia species (Porifera, Demospongiae, Tetractinellida) in the Atlantic boreo-arctic region. Zoological Journal of the Linnean Society 169, 251-311.

Cerjanec, D., Kučinić, M., Vilenica, M., Ćukušić, A., Ćuk, R., Ibrahimi, H., Vučković, I., Žalac, S. \& Ruk, D., 2020: Ecological and faunistic features of caddisflies (Insecta: Trichoptera) in different types of habitats in the Dinaric karst area (Central Croatia). Ecologica Montenegrina 36, 6-39.

Ćuk, R. \& Vučković, I., 2009: First record of caddisfly Rhyacophila laevis Pictet, 1834 (Insecta: Trichoptera) in Croatia. Natura Croatica 18 (2), 449-453.

Ćuk, R. \& VučKović, I., 2010: Ironoquia dubia Stephens, 1837 (Insecta: Trichoptera), a caddisfly species new for Croatia. Natura Croatica 19 (1), 231-237.

Ćuk, R. \& Vučković, I., 2014: The first record of caddisfly Setodes viridis (Fourcroy, 1875) (Insecta: Trichoptera) in Croatia. Natura Croatica 23 (2), 407-413. 
Ćuk, R., Vučković, I., Kučinić, M., Valić, D. \& Waringer, J., 2015: First record of Beraea dira McLachlan 1875 (Insecta, Trichoptera, Beraeidae) in Croatia. Natura Croatica 24 (2), 311-316.

Ćukušić, A., Ćuk, R., Previšić, A., Podnar, M., Delić, A., Kučinić, M., 2017: DNA barcoding and first records of two rare Adicella species (Trichoptera: Leptoceridae) in Croatia. Biologia (Slovakia) 72 (7), 796-806.

Darriba, D., Taboada, G. L., Doallo, R. \& Posada, D., 2012: jModelTest 2: more models, new heuristics and parallel computing. Nature Methods 9 (8), 772.

Dela Cruz, J. N. B., Nuñeza, O. M. \& Lin, C-P., 2016: Description of a new Oriental stonefly species, Phanoperla constanspina (Plecoptera: Perlidae) from Mindanao, Philippines and association of life stages using DNA barcoding. Zootaxa 4193, 102-116.

Elías-Gutiérrez, M., Jerónimo, F. M., Ivanova, N. V., Valdez-Moreno, M. \& Hebert, P. D. N., 2008 : DNA barcodes for Cladocera and Copepoda from Mexico and Guatemala, highlights and new discoveries. Zootaxa 1839, 1-42.

Folmer, O., Black, M., Hoeh, W., Lutz, R. \& Vrijenhoek, R., 1994: DNA primers for amplification of mitochondrial cytochrome c oxidase subunit I from diverse metazoan invertebrates. Molecular Marine Biology and Biotechnology 3, 294-299.

Graf, W., Kučinić, M., Previšić, A., Vučković, I. \& Waringer, J., 2008a: The larva, ecology and distribution of Tinodes braueri McLachlan, 1878 (Trichoptera: Psychomyiidae). Aquatic insects 30 (4), 295-299.

Graf, W., Murphy, J., Dahl, J., Zamora-Muñoz, C. \& López-Ronríguez, M. J., 2008b: Distribution and ecological preferences of European freshwater organisms. Volume 1. Trichoptera. Pensoft, Sofia-Moscow, 388 pp.

HRN EN 16150, 2012: Water quality - Guidance on pro-rata Multi-Habitat sampling of benthic macro-invertebrates from wadeable rivers, $12 \mathrm{pp}$.

Habdja, I. \& Primc, B., 1987: Biocenotical classification of the lithoreophilous communities in the karst running waters according to the macro benthic fauna. Acta Hydrochimica et Hydrobiologica 15 (5), 495-503.

Habdja, I., Primc-Habdja, B. \& Belinić, I., 1994: Functional community organization of macroinvertebrates in lotic habitats of the Plitvice Lakes. Acta Hydrochimica et Hydrobiologica 22 (2), 85-92.

Habdija, I., Radanović, I. \& Primc-Habdja, B., 1997: Longitudinal distribution of predatory benthic macroinvertebrates in a karstic river. Archiv für Hydrobiologie 139 (4), 527-546.

Habdija, I., Radanović, I. \& MatoničKin, R., 2000: Functional feeding structure of benthic macroinvertebrates in travertine barrier biotopes. Verhandlungen - Internationale Vereinigung für Theoretische und Angewandte Limnologie 27, 2594-2599.

Habdja, I., Radanović, I., Primc-Habdja, B. \& Špoljar, M., 2002: Vegetation cover and substrate type as factors influencing the spatial distribution of trichopterans along a karstic river. International Review of Hydrobiology 87 (4), 423-437.

Habdija, I., Radanović, I., Primc-Habdija, B., Matoničkin, R. \& Kučinić, M., 2003: River discharge regime as a factor affecting the changes in community and functional feeding group composition of macroinvertebrates on a cobble substrate in Sava River. Biologia, Section Zoology 58 (2), 217229.

Habdija, I., Primc-Habdija, B., Matoničkin, R., Kučinić, M., Radanović, I., Miliša, M. \& Mihaljević, Z., 2004: Current velocity and food supply as affecting the composition of macroinvertebrates in bryophyte habitats in karst running water. Biologia (Bratislava) 59 (5), 577-593.

Hebert, P. D. N., Cywinska, A., Ball, S. L. \& de WaArd, J. R., 2003a: Biological identifications through DNA barcodes. Proceedings of the Royal Society B 270, 313-321.

Hebert, P. D. N., Ratnasingham, S. \& de Waard, J. R., 2003b: Barcoding animal life: Cytochrome c oxidase subunit 1 divergences among closely related species 2003b: Proceedings of the Royal Society B: Biology letters 270 (Supp. 1), pp. S96-S99.

Illies, J., 1978: Limnofauna Europaea. Gustav Fischer Verlag, Stuttgart, 532 pp.

Karaouzas, I., Graf, W., Kučinić, M., VučKović, I. \& Waringer, I., 2015: The larva of Rhyacophila balcanica Radovanovic 1953 (Trichoptera: Rhyacophilidae) with notes on ecology. Zootaxa 4057 (3), 444-450.

Katoh, K. \& Standley, D. M., 2013: MAFFT Multiple Sequence Alignment Software Version 7: improvements in performance and usability. Molecular Biology and Evolution 30 (4), 772-780. 
Kladarić, L., Popijač, A., Hlebec, D., Previšić, A., Ćuk, R., Vuč́ović, I. \& Kučinić, M., 2021: A suprising finding of Ecclisopteryx asterix Malicky, 1979 (Insecta, Trichoptera) in Croatia with notes to DNA barcoding and new distributional data of the subfamily Drusinae. Ecologica Montenegrina $48,71-85$.

KuČINIĆ, M., 2002: Biodiversity and distribution of caddisflies (Trichoptera, Insecta) of Plitvice Lakes. - PhD- Thesis, Faculty of Science, University of Zagreb, 139 pp.

KuČinıć, M. \& MALıcKY, H., 2002: Rhyacophila dorsalis plitvicensis, a new subspecies (Trichoptera: Rhyacophilidae) from Croatia. Proceedings of the 10th International Symposium on Trichoptera (Ed. Wolfram Mey). Nova Supplementa Entomologica 15, 145-147.

Kučinić, M., Previšić, A., Gottstein, S., Hrašovec, B., Stanić-Koštroman S., Pernek, M., Delić, A., 2008: Description of the larvae of Drusus radovanovici septentrionis Marinković-Gospodnetić, 1976 and Drusus croaticus Marinković-Gospodnetić, 1971 (Trichoptera: Limnephilidae) from Bosnia and Herzegovina and Croatia. Zootaxa 1783, 1-17.

KuČinić, M., BuČAr, M. \& Delić, A., 2010: Prvi prilog poznavanju faune tulara (Insecta, Trichoptera) na području Banovine. In: Bučar M. (Ed) Zrinska gora: Regionalni park prirode. Grad Petrinja: Učiteljski fakultet: Matica hrvatska, Ogranak; Sisačko-Moslavačka županija; Sveučilište u Zagrebu, Petrinja - Sisak - Zagreb, pp. 226-235.

Kučinić, M., VučKović, I., Kutnjak, H., Š́erić Jelaska, L., \& Marguš, D., 2011: Diversity, distribution, ecology and biogeography of caddisflies (Insecta: Trichoptera) in the Krka River (National Park "Krka", Croatia). Zoosymposia 5, 255-268.

Kư̌inić, M., Szivák, I., Pauls, S. U., Bálint, M., Delić, A. \& Vuč́ović, I., 2013: Chaetopteryx bucari sp. n. a new species from the Chaetopteryx rugulosa group from Croatia (Insecta, Trichoptera) with some molecular, taxonomical and ecological notes on the group. Zookeys 320, 1-28.

Kučinić, M., Previšić, A., Vajdić, M., Tunjić, M., Minoci, I., Žalac, S., Sviben, S., Vučrović, I., TrupKović, M. \& Habdja I., 2017: First systematic investigation of adults and second checklist of caddisflies of the Plitvice Lakes National Park with notes on research history, biodiversity, distribution and ecology. Natura Croatica 26 (2), 225-260.

Kučinić, M., Ćukušić, A., Delić, A., Podnar, M., Gumhalter, D., Mičetić Stanković, V., Plantak, M., Čeple, G., Plavec, H. \& Marguš, D., 2019: New species from the family Hydroptilidae in Croatian fauna collected in the Krka National Park with particular notice to biodiversity and DNA barcoding. Natura Croatica 28 (2), 441-454.

Kučinić, M., Ćukušić, A., Ibrahimi, H., Plantak, M., Vuković, M., Bukvić, V. \& Vučković, I., 2020a: DNA barcoding and a new taxonomic status of the Triaenodes ochreellus lefkas Malicky, 1974 (Insecta, Trichoptera) with new distribution data. Ecologica Montenegrina 38, 172-185.

Kučinić, M., Delić, A., BuČar, M., Plavec, H., Čeple, G., Ćukušıć, A., Ćuk, R., Cerjanec, D., Vučković, I. \& GJuRAš̀n, B., 2020b: Prvi nalaz tulara Agraylea sexamaculata Curtis, 1834 (Insecta, Trichoptera) na području kontinentalnog dijela Hrvatske s nadopunjenom check-listom Trichoptera Banovine i kratkim osvrtom na DNA barkodiranje. Zrinska gora regionalni park (Ed. Bučar, M.), 70-79.

Kumar, S., Stecher, G., Li, M., Knyaz, C. \& Tamura, K., 2018: MEGA X: Molecular Evolutionary Genetics Analysis across computing platforms. Molecular Biology and Evolution 35 (6), 1547-1549.

Lechthaler, W. \& Stockinger, W., 2007: Trichoptera - Key to Larvae from Central Europe. Gustav Stresemann Institut e. V. Deutsche Gesellschaff für Limnologie.

Malicky, H. \& KruŠnik, C., 1988: Chaetopteryx marinkovicae sp. n. (Trichoptera, Limnephilidae) from Istria, Yugoslavia. Aquatic Insects 11 (3), 180.

Malicky, H., 2004: Atlas of European Trichoptera, Second Edition, Springer, 359 pp.

Malicky, H., Previšıć, A. \& KuČinić, M., 2007: Rhyacophila cabrankensis nov. spec. from Croatia. Braueria 34,14 .

Malıcky, H., 2009: Die Köcherfliegen (Insecta: Trichoptera) der Sammlung von Franjo Košćec im Museum Varaždin, Kroatien. Natura Croatica 18 (1), 129-134.

Malicky, H., 2013: Trichoptera, Caddisflies. Fauna Europaea version 2017.06, https://fauna-eu.org (accessed on August 11 $1^{\text {th }}$ 2021)

Malicky, H., 2014: Lebensräume von Köcherfliegen (Trichoptera). Denisia, 34, 1-280.

Marinković-Gospodnetić, M., 1971: The species of the genus Drusus in Yugoslavia. Godišnjak Biološkog Instituta Univerziteta Sarajevo (Annual of the Institute of Biology - University of Sarajevo) 24, 105-109. 
Marinković-Gospodnetić, M., 1979: Trichoptera (Insecta) velikih karstnih izvora u Dinaridima. In: Rauš, Đ. (Ed.), Drugi kongres Ekologa Jugoslavije (Second Congress of Ecologists of Yugoslavia). Savez društava ekologa Jugoslavije. Zagreb, pp. 1837-1849.

MatoničKin I. \& PAvletić Z., 1961: Biljni i životinjski svijet na sedrenim slapovima jugoslavenskih krških voda. Biološki glasnik 14, 105-128.

Matoničkin I. \& Pavletić Z., 1965: Biološka klasifikacija gornjih tijekova krških rijeka. Acta Botanica Croatica 24, 151-162.

Matoničkin I., Pavletić Z., Habdija I. \& Stilinović B., 1969: Prilog limnologiji gornjeg toka rijeke Save. Ekologija 4, 91-124.

Matoničkin, R., Habdija, I. \& Primc-Habdija, B., 2001: The effects of season and food availability on macroinvertebrate colonization in a woodland stream. Archiv für Hydrobiologie, 153 (1), 55-74.

Morinière, J., Hendrich L., Balke, M., Beermann A. J., König, T., Hess, M., Koch, S., Müller, R., Leese, F., Hebert, P. D. N., Hausmann, A., Schubart, C. D. \& Haszprunar, G., 2017: A DNA barcode library for Germanys mayflies, stoneflies and caddisflies (Ephemeroptera, Plecoptera and Trichoptera). Molecular Ecology Resources 17, 1293-1307.

Morse, J. C., 2021: Trichoptera World Checklist. http://entweb.clemson.edu/database/trichopt/ index.htm (Accessed 4 August 2021)

Official Gazette, 2013: Regulation on Water Quality Standard. Official Gazette of the Republic of Croatia No. 73/13, 151/14, 78/15, 61/16, 80/18.

Olah, J., 2011: New species and records of Balkan Trichoptera. Folia Historico Naturalia Musei Matraensis 35, 111-121.

Previšić A., Kerovec, M. \& Kučinić, M., 2007a: Emergence and Composition of Trichoptera from Karst Habitans, Plitvice lakes Region, Croatia. International Review of Hydrobiology 92 (1), 61-83.

Previšić, A., Mihaljević, Z. \& Kerovec, M., 2007b: Caddisfly Insecta: Trichoptera) fauna of altered and man-made habitats in Drava river, NW Croatia. Natura Croatica 16 (3), 181-187.

Previšić, A., Graf, W. \& Kučinić, M., 2010: Caddisfly (Trichoptera) fauna of the Plitvice Lakes National Park, Croatia. Denisia 29, 287-294.

Previšić, A. \& Popijač, A., 2010: Fauna tulara (Insecta: Trichoptera) Kupe, Čabranke i njihovih pritoka (Gorski kotar, zapadna Hrvatska). Natura Croatica 19 (2), 357-368.

Previšić, A., Ivković, M., Miliša, M. \& Kerovec, M., 2013: Caddisfly (Insecta: Trichoptera) fauna of the Papuk Nature Park, Croatia. Natura Croatica 22 (1), 1-13.

Previšić, A., Graf, W., Vitecek, S., Kučinić, M., Bálint, M., Keresztes, L., Pauls, S. U. \& Waringer, J., 2014: Cryptic diversity of caddisflies in the Balkans: the curious case of Ecclisopteryx species (Trichoptera: Limnephilidae). Arthropod Systematics \& Phylogeny 72 (3), 309-329.

RaĐA, B. \& Puljas, S., 2010: Do Karst Rivers "deserve" their own biotic index? A ten years study on macrozoobenthos in Croatia. International Journal of Speleology 39 (2), 137-147.

Ratnasingham, S. \& Hebert, P. D. N., 2007: bold: The Barcode of Life Data System (http:/ /www.barcodinglife.org). Molecular Ecology Notes 7 (3), 355-364.

Ridl, A., Previšić, A., Ivković, M. \& Mihaljević, Z., 2015: Emergencija tulara (Trichoptera, Insecta) sedrenih barijera u NP "Krka". Zbornik radova o NP Krka (ed. Marguš, D.), 183-194.

Szivák, I., Mikes, T., Szalontai, B., Kučinić, M., Vučković, I., Vadkerti, E., Kisfali, P., Pauls, S. U. \& BÁlint, M., 2017: Ecological divergence of Chaetopteryx rugulosa species complex (Insecta, Trichoptera) linked to climatic niche diversification, Hydrobiologia 794, 31-47.

Tyagi, K., Kumar, V., Singha, D., Chandra, K., Laskar, B. A. Kundu, S., Chakraborty, R. \& Sumantika Chatterjee, S., 2017: DNA Barcoding studies on Thrips in India: Cryptic species and Species complexes. Scientific Reports 7, Article number 4898.

Vaglia, T., Haxaire, J., Kitching, I. J., Meusnier, I. \& Rougerie, R., 2008: Morphology and DNA barcoding reveal three cryptic species within the Xylophanes neoptolemus and loelia species-groups (Lepidoptera: Sphingidae). Zootaxa 1923, 18-36.

Valladolid, M., Kučinić, M., Arauzo, M., Cerjanec, D., Ćuk, R., Dorda, B., Lodovici, O., Stanić-Koštroman, S., Vučrović, I. \& Rey, I., 2020: The Rhyacophila fasciata Group in Croatia and Bosnia and Herzegovina: Rhyacophila f. fasciata Hagen 1859 and the description of two new subspecies, Rhyacophila fasciata delici Kučinić \& Valladolid (ssp. nov.) from Croatia and Bosnia and Herzegovina and Rhyacophila fasciata viteceki Valladolid \& Kučinić (ssp. nov.) from Bosnia and Herzegovina (Trichoptera: Rhyacophilidae). Zootaxa 4885 (1), 051-075. 
ViJayan, K. \& Tsou, H. C., 2010: DNA barcoding in plants: Taxonomy in a new perspective, Current science 99 (11), 1530-1541.

Villesen, P., 2007: FaBox: an online toolbox for fasta sequences. Molecular Ecology Notes 7, 965-968.

Vrućina, I., Previšić, A. \& Merdić, E., 2016: First record of Oecetis furva (Rambur, 1842) and Orthotrichia tragetti (Mosely, 1930) (Insecta, Trichoptera) for the Croatian fauna. Natura Croatica 25 (1), 109-118.

Vučković, I., Previšić, A., Graf, W. \& Kučinić, M., 2011: Description of the female and new data on distribution of Annitella apfelbecki Klapalek, 1899 (Insecta: Trichoptera). Aquatic Insects 33(4), 381389.

Vučrović, I., KuČinić, M., Ćukušsć, A., Vuković, M., Ćuk, R., Stanić-Koštroman, S., Cerjanec, D. \& PlantAK, M., 2021: Biodiversity, DNA barcoding data and ecological traits of caddisflies (Insecta, Trichoptera) in the catchment area of the Mediterranean karst River Cetina (Croatia). Ecologica Montenegrina 44, 19-25.

Wallace, I. D., Wallace B. \& Philipson G. N., 1990: A key to the case-bearing caddis larvae of Britain and Ireland. Freshwater Biological Association, Ambleside, 259 pp.

Waringer, J., Graf, W., Kučinić, M., Previšić, A. \& Vuč́ović, I., 2009: The Larva and life cycle of Annitella apfelbecki Klapalek, 1899, including a re-description of Melampophylax nepos McLachlan, 1880 (Trichoptera: Limnephilidae). Aquatic insects 31 (1), 71-80.

WARINGer, J. \& GRAF, W., 2011: Atlas der mitteleuropäischen Köcherfliegenlarven - Atlas of Central European Trichoptera Larvae. Dinkelscherben: Erik Mauch Verlag.

\title{
SAŽETAK
}

\section{Prvi nalaz tulara Cyrnus crenaticornis (Kolenati, 1859) (Insecta, Trichoptera, Polycentropodidae) u Hrvatskoj: morfološka determinacija i DNA barkodiranje}

\author{
R. Ćuk, M. Kučinić, L. Kladarić, D. Hlebec, V. Đanić \& M. Miličić
}

Fauna tulara (Trichoptera) Hrvatske trenutno broji oko 210 vrsta, a nove vrste i nalazi se relativno često utvrđuju velikim dijelom zahvaljujući DNA barkodiranju. Ova je metoda postala odlična nadopuna standardnom morfološkom određivanju vrsta. Iako se identifikacija vrsta, kao i taksonomska istraživanja najčešće provode na odraslim jedinkama koje se smatraju pouzdanijima, ličinke tulara su također dobar izvor informacija. Ovim radom se prvi puta spominje vrsta Cyrnus crenaticornis (Kolenati, 1859) za Hrvatsku, pronađena u rijeci Odri u mjestu Čička Poljana u kolovozu 2015. godine s 21 utvrđenim primjerkom. Identifikacija je provedena na temelju morfoloških značajki ličinki, a potvrđena je i DNA barkodiranjem. Utvrđeni nalaz je vrijedan doprinos poznavanju faune Hrvatske. 